\title{
Central Memory T-Lymphocyte
}

National Cancer Institute

\section{Source}

National Cancer Institute. Central Memory T-Lymphocyte. NCI Thesaurus. Code

C126420.

Long-lived antigen-specific T-lymphocytes, which express CD4, L-selectin and CCR7.

Upon subsequent exposure to their target antigen, these cells rapidly proliferate and differentiate into effector cells. 